\title{
The Analysis of Teacher Candidates' Self-Sufficiency about Their Teaching Abilities at Different Departments
}

\author{
Levent VAR ${ }^{1}$ \\ 'University of Kirsehir Ahi Evran, School of Physical Education and Sports, Kirsehir, Turkey \\ Email:levent.var@ahievran.edu.tr Tel:5422550131
}

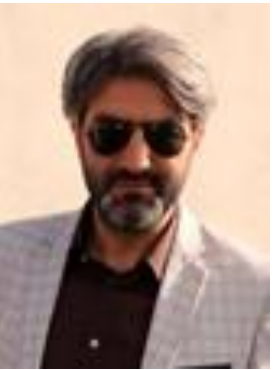

\begin{abstract}
Self-sufficiency is an individual's perception of his/her ability and skills to overcome various possible situations. This study aims to analyze self-sufficiency about their teaching abilities of teacher candidates studying at different departments at University of Kırşehir Ahi Evran. The research groups consists of 244 teacher candidates who study classroom teaching, mathematics teaching and Turkish language teaching at Faculty of Education and physical education and sports teaching, coaching education and sports management at School of Physical Education and Sports and attend a teaching formation program. Mean age of the students participating in the study is $\bar{x}=22.52$. SPSS 22.0 package program for Windows was used for descriptive and One-way ANOVA analysis, and the level of significance was taken as 0.05. When self-sufficiency points of different departments are analyzed, it can be observed that students of physical education had the highest point as $93.09 \pm 24.07$, while students of classroom teaching had the lowest point as $58.64 \pm 14.03$
\end{abstract}

Keywords: Teacher candidate, Teaching, Self-sufficiency.

Citation | Levent VAR (2018). The Analysis of Teacher Candidates' Self-Sufficiency about Their Teaching Abilities at Different Departments. Asian Journal of Education and Training, $4(3): 246-249$.

History:

Received: 22 June 2018

Revised: 4 July 2018

Accepted: 6 July 2018

Published: 12 July 2018

Licensed: This work is licensed under a Creative Commons

Attribution 3.0 License (cc))

Publisher:Asian Online Journal Publishing Group
Funding: This study received no specific financial support

Competing Interests: The author declares that there are no conflicts of interests regarding the publication of this paper.

Transparency: The author confirms that the manuscript is an honest, accurate, and transparent account of the study was reported; that no vital features of the study have been omitted; and that any discrepancies from the study as planned have been explained.

Ethical: This study follows all ethical practices during writing.

\section{Contents}

1. Introduction

2. Material and Method.

4. Discussion. 


\section{Introduction}

The notion of self-sufficiency belief is related to an individual's thoughts and perceptions of him/herself (Bandura, 1982). In other words, it can be expressed as an individual's belief in their ability to control themselves against difficult tasks and their own practices (Luszczynska et al., 2005).

An individual's confidence in his/her future and belief in his/her own self-sufficient is an important factor in terms of attaining professional success. In addition, such belief and confidence will play an important role in an individual's own capacity to face and solve problems in various areas of their professional education and business lives (Yilmaz et al., 2010).

Lewitt (2001) argues that a teacher's beliefs and perceptions about teaching, learning and students will enable $\mathrm{him} /$ her to maintain a certain attitude and affect his/her behaviors. Thus, self-sufficiency belief comes to the forefront as one of the most important aspects in teacher training (Pajares, 1996). Individuals with a higher level of self-sufficiency belief are assumed to offer solutions to their problems more easily (Blumenfeld et al., 1991).

Teacher self-sufficiency belief is defined as a teacher's perception of his/her capacity and skills in terms of reaching intended results for student commitment and learning (Tschannen-Moran and Woolfolk- Hoy, 2001).

It is acknowledged that a teacher's self-sufficiency belief in teaching heavily influences his/her teaching performance (Brownell and Pajares, 1999). A teacher's competence is directly related to his/her teaching practices and a high self-sufficiency belief (Rimn-Kaufman et al., 2004). A teacher candidate's perception of his/her confidence in his/her teaching competence increases the expectations about their future competence. On the other hand, a perception of low performance increases their confidence in their competence, and thus results in an expectation of unsuccessful performance in the future (Atici, 2001). In addition, teacher self-sufficiency directly influences education quality (Chan, 2008).

\section{Material and Method}

\subsection{Research Group}

The research groups consists of 244 teacher candidates who study classroom teaching, mathematics teaching and Turkish language teaching at Faculty of Education and physical education and sports teaching, coaching education and sports management at School of Physical Education and Sports and attend a teaching formation program at University of Kırşehir Ahi Evran. Mean age of the students participating in the study is $\bar{x}=22.52$.

\subsection{Data Collection Tools}

The data of this study were collected from students study in spring semester in 2017-2018. A data collection tool consisting of Personal Information Form (PIF) and Teacher Competence Expectation Inventory (TCEI) were voluntarily filled by students during class breaks. Prior to these sessions, the researchers informed the students about the scales in these forms.

\subsubsection{Personal Information Form (PIF)}

A Personal Information Form was prepared in order to obtain personal information from teacher candidates studying at different departments at University of Kırşehir Ahi Evran. This form aimed at collecting data about various properties that were considered important about students' self-sufficiency levels in teaching.

\subsubsection{Teacher Competence Expectation Inventory (TCEI)}

In this study, "Teacher Competence Expectation Inventory (TCEI)" consisting of 38 articles and developed for YOK/World Bank National Education Development Project in 1998 was used in order to determine selfsufficiency levels of teacher candidates studying at classroom teaching, mathematics teaching and Turkish language teaching at Faculty of Education and physical education and sports teaching, coaching education and sports management at school of physical education and sports about their teaching abilities (Tekkursun, 2015).

\subsection{Statistical Analyses}

SPSS 22.0 package program for Windows was used for descriptive and One-way ANOVA analysis, and the level of significance was taken as 0.05 .

\section{Findings}

Table-1. Descriptive statistics of the study

\begin{tabular}{l|c|c|c}
\multicolumn{4}{c}{ Table-1. Descriptive statistics of the study } \\
\hline Variables & $\mathbf{N}$ & $\mathbf{\%}$ & Mean age $\mathbf{x} \pm \mathbf{s d}$ \\
\hline Classroom Teaching & 50 & 20.5 & $22.70 \pm 1.12$ \\
\hline Mathematics Teaching & 51 & 20.9 & $21.60 \pm 0.96$ \\
\hline Turkish Language Teaching & 50 & 20.5 & $22.71 \pm 1.96$ \\
\hline Physical Education Teaching & 31 & 12.7 & $22.96 \pm 2.00$ \\
\hline Coaching Education & 30 & 12.3 & $22.86 \pm 1.40$ \\
\hline Sports Management & 32 & 13.1 & $22.68 \pm 1.85$ \\
\hline Total & 244 & 100 & $22.52 \pm 1.61$ \\
\hline
\end{tabular}

The percentage of each department participating in the study is $20.5 \%$ for classroom teaching ( $\mathrm{n}=50$ ), $20.9 \%$ for mathematics teaching $(n=51), 20.5 \%$ for Turkish language teaching $(n=50), 12.7 \%$ for physical education teaching $(n=31), 12.3 \%$ for coaching education $(n=30)$ and $13.1 \%$ for sports management $(n=32)$. Mean age of the students participating in the study is $\overline{\mathrm{x}}=22.52 \pm 1.61$. 
Table-2. Self-sufficiency points of all departments

\begin{tabular}{l|l|l|l}
\hline Faculty/School & Departments & $\mathbf{n}$ & $\mathbf{x} \pm \mathbf{s d}$ \\
\hline \multirow{4}{*}{ Faculty of Education } & Mathematics & 51 & $76.45 \pm 15.63$ \\
\cline { 2 - 4 } & Turkish Language & 50 & $73.30 \pm 18.01$ \\
\cline { 2 - 4 } & Classroom Teaching & 50 & $58.64 \pm 14.03$ \\
\hline \multirow{4}{*}{ School of Physical Education and Sports } & Physical Education Teaching & 31 & $93.09 \pm 24.07$ \\
\cline { 2 - 4 } & Coaching Education & 30 & $83.76 \pm 18.23$ \\
\cline { 2 - 4 } & Sports Management & 32 & $65.25 \pm 24.16$ \\
\cline { 2 - 4 } Total & & 244 & $73.70 \pm 21.43$ \\
\hline
\end{tabular}

When the self-sufficiency points of all departments participating in the study are analyzed, it can be noted that students at physical education teaching had the highest level with 93.09 \pm 24.07 , while students at classroom teaching had the lowest level with $58.64 \pm 14.03$.

Table-3. Comparison of self-sufficiency points of students studying at school of physical education and sports and faculty of education

\begin{tabular}{|c|c|c|c|}
\hline Department & Department & Mean Difference & $\mathbf{p}$ \\
\hline \multirow{3}{*}{ Physical Education Teaching } & Classroom & $34.45677^{*}$ & $.000^{* * *}$ \\
\hline & Mathematics & $16.64579^{*}$ & $.002^{* *}$ \\
\hline & Turkish Language & $19.79677^{*}$ & $.000^{* * * *}$ \\
\hline \multirow{3}{*}{ Coaching Education } & Classroom & $25.12667^{*}$ & $.000^{* * *}$ \\
\hline & Mathematics & 7.31569 & .531 \\
\hline & Turkish & 10.46667 & .151 \\
\hline \multirow{3}{*}{ Sports Management } & Classroom & 6.61000 & .623 \\
\hline & Mathematics & -11.20098 & .087 \\
\hline & Turkish & -8.05000 & .402 \\
\hline
\end{tabular}

${ }^{* *} \mathrm{p}<0.01{ }^{* * * *} \mathrm{p}<0.001$

When self-sufficiency points of students studying at school of physical education and sports and faculty of education are compared, a significance level of .000 ( $\mathrm{p}<0.001)$ was found between students at physical education teaching and classroom teaching and Turkish language teaching, and between students at coaching education and classroom teaching.

Table-4. Self-sufficiency points based on different departments at School of Physical Education and Sports

\begin{tabular}{l|l|l|l}
\hline Department & Department & Mean Difference & $\mathbf{p}$ \\
\hline \multirow{2}{*}{ Physical Education Teaching } & Coaching Education & 9.33011 & .271 \\
\cline { 2 - 4 } & Sports Management & $27.84677^{*}$ & $.000^{* * *}$ \\
\hline \multirow{2}{*}{ Coaching Education } & Physical Education Teaching & -9.33011 & .271 \\
\cline { 2 - 4 } & Sports Management & $18.51667^{*}$ & $.007^{* *}$ \\
\hline \multirow{2}{*}{ Sports Management } & Physical Education Teaching & $-27.84677^{*}$ & $.000^{* * *}$ \\
\cline { 2 - 4 } & Coaching Education & $-18.51667^{*}$ & $.007^{* *}$ \\
\hline${ }^{* *} \mathrm{p}<0.01{ }^{* * *} \mathrm{p}<0.001$ & &
\end{tabular}

When self-sufficiency points of students studying at different departments of school of physical education and sports are compared, a significance level of .000 $(p<0.001)$ was found between students at physical education teaching and sports management.

\section{Discussion}

This study was conducted to determine self-sufficiency of teacher candidates studying at different departments, and it was found out that students of physical education had the highest perception of self-sufficiency as 93.09 \pm 24.07 , while students of classroom teaching had the lowest perception of self-sufficiency as 58.64 \pm 14.03 . Although this may be associated with different factors, it is reasonable to assume that students of physical education teaching are more sociable and, thanks to sport, have a higher confidence in their self-sufficiency compared to other departments.

Similar to the findings in the present study, Tekkursun (2015) reported a high level of self-sufficiency among students of physical education teaching participating in his study, and concluded that teacher candidates viewed themselves as competent enough to fulfill their own profession.

Seker et al. (2005) demonstrated in their findings that teacher candidates did not consider themselves, their lecturers and classmates as self-sufficient about their teaching abilities. It was also reported that female teacher candidates regarded themselves as more self-sufficient compared to their male classmates. No significant difference was found between perceptions of self-sufficiency in teacher candidates studying at social sciences and science/mathematics teaching departments.

Twenge and Campbell (2008) too, focuses on self-sufficiency in their study. Unlike this study, however, it was indicated in this study that high school students in 2006 had a much lower self-perception point compared to high school students in 1975. In addition, the findings suggested that self-sufficiency levels did not increase from one generation to the other, whereas there was an increase in self-expectations.

Yenilmez and Kakmaci (2008) in a similar vein, attempted to determine levels of self-sufficiency belief in teacher candidates studying at primary school mathematics teaching departments, and reported that their level of 
self-sufficiency belief was high when it comes to issues that students could fulfill with their own efforts, while this level was lower for issues for which they needed other individuals' help.

Kaldi (2009) carried out a study to determine teacher candidates' perception of self-sufficiency and their feelings and stress during classes, and observed that teacher candidates felt themselves competent enough to start teaching and that their levels of general teaching techniques were above average. This study also concluded that teacher candidates needed to improve their positive teaching experiences and efficient teaching capacities.

Jennings and Greenberg (2009) developed a model that underlines the importance of teachers' social and emotional competence (SEC) in class environment. This model improves the interaction between teacher and students, and provides an efficient class management and a successful social and emotional learning environment. In addition, it contributes to students' positive learning and development in class environment. Because selfsufficiency occupies an important position in teaching as a profession, similar programs must be definitely used by teachers.

Kafkas et al. (2010) analyzed self-sufficiency levels of teacher candidates study at physical education teaching and suggested that students of physical education teaching be compared with students at other departments of faculty of education. In this respect, the present study was conducted among teacher candidates studying at school of physical education and sports and faculty of education.

The findings of the present study and similar above-mentioned articles demonstrate that a high level of selfsufficiency belief bears importance in a teacher candidate's self-confidence, efficiency and success in his/her profession. Therefore, further studies are needed to shed light on self-confidence and social activity levels of teacher candidates in various departments as well as their self-sufficiency levels.

\section{References}

Atici, M., 2001. Teacher competence. Educational Administration: Theory and Practice, 26: 195- 209.

Bandura, A., 1982. Self-efficacy mechanism in human agency. American Psychologist, 37(2): 122-147. View at Google Scholar $\mid$ View at Publisher

Blumenfeld, P., E. Soloway and R.A. Marx, 1991. Motivating project based learning: Sustaining the doing, supporting the learner. Educational Psychologist, 26(3-4): 369-398. View at Google Scholar | View at Publisher

Brownell, M.T. and F. Pajares, 1999. Teacher efficacy and perceived success in mainstreaming students with learning and behavior problems. Teacher Education and Special Education, 22(3): 154-164. View at Google Scholar $\mid$ View at Publisher

Chan, D.W., 2008. General, collective, and domain specific teacher self-efficacy among Chinese prospective and in-service teachers in Hong Kong. Teaching and Teacher Education, 24(1): 1057-1069. View at Google Scholar $\mid$ View at Publisher

Jennings, P.A. and M.T. Greenberg, 2009. The prosocial classroom: Teacher social and emotional competence in relation to student and classroom outcomes. Review of Educational Research, 79(1): 491-525. View at Google Scholar |View at Publisher

Kafkas, M.E., M. Acak, B. Coban and T. Karademir, 2010. Investigation of the relationship between preservice physical teacher s' sense of self efficacy and professional concerns. Inonu University Journal of the Faculty of Education, 11(2): 93-111. View at Google Scholar

Kaldi, S., 2009. Student teachers' perceptions of self-competence in and emotions/stress about teaching in initial teacher education. Journal Educational Studies, 35(3): 349-360. View at Google Scholar | View at Publisher

Lewitt, K.E., 2001. An analysis of elementary teachers' belief regarding the teaching and learning of science. Science Education, 86(1): 1-22. View at Google Scholar | View at Publisher

Luszczynska, A., B. Gutiérrez-Doña and R. Schwarzer, 2005. General self-efficacy in various domains of human functioning: Evidence from five countries. International Journal of Psychology, 4O(2): 80-89. View at Google Scholar $\mid$ View at Publisher

Pajares, F., 1996. Self-efficacy beliefs in academic settings. Review of Educational Research, 66(4): 543-578. View at Google Scholar $\mid$ View at Publisher

Rimn-Kaufman, S., E. Sara and B. Sawyer, 2004. Primary grade teachers selfefficacy belief, attitudes towards teaching, and discipline and teaching practice priorities in relation to the responsive classroom approach. Elementary School Journal, 104(4): 321-341. View at Google Scholar | View at Publisher

Seker, H., S. Deniz and I. Gorgen, 2005. Prospective teachers' assessment of teacher competencies. Educational Administration: Theory and Practice, 42(11): 237-253. View at Google Scholar

Tekkursun, G., 2015. Analyses of self-efficacy of physical education teacher candidates (Gazi University and Kafkas University sample). Master Thesis. Gazi University, Institute of Educational Sciences.

Tschannen-Moran, M. and A. Woolfolk- Hoy, 2001. Teacher efficacy: Capturing an elusive construct. Teaching and Teacher Education, 17(7): 783-805. View at Google Scholar $\mid$ View at Publisher

Twenge, J.M. and W.K. Campbell, 2008. Birth-cohort changes in anticipated performance, self-satisfaction, self-liking, and self-competence, assosiation of social science. Psyological Social Science, 19(11): 1082-1086. View at Google Scholar

Yenilmez, K. and O. Kakmaci, 2008. The level of self-efficacy beliefs at students at elementary mathematics education department. Eskisehir Osmangazi University Social Sciences Journal, 9(2): 1-21.

Yilmaz, G., B. Yilmaz and N. Turk, 2010. Over-graduate thesis physical education and sports teacher's self efficacy of their jobs (Nevsehir City Model). Selcuk University Journal of Physical Education and Sport Science, 12(2): 85-90. View at Google Scholar 